\title{
HIF-1 $\alpha$-Deficient Mice Have Increased Brain Injury after Neonatal Hypoxia-Ischemia
}

\author{
R. Ann Sheldon ${ }^{\text {a }}$ Damjan Osredkar ${ }^{\text {Christina L. Lee }}{ }^{\mathrm{a}}$ Xiangning Jiang $^{\mathrm{a}}$ \\ Dezhi Mu ${ }^{a, c}$ Donna M. Ferriero ${ }^{a, b}$ \\ Departments of a Neurology and ${ }^{b}$ Pediatrics, University of California, San Francisco, Calif., USA; \\ 'Department of Pediatrics, West China Second University Hospital, Sichuan University, Chengdu, China
}

\section{Key Words}

Brain injury $\cdot$ Transcription factor $\cdot$ Hypoxia-inducible

factor $1 \alpha \cdot$ Neonatal hypoxia-ischemia

\begin{abstract}
Evidence suggests that the activation of the transcription factor hypoxia-inducible factor $1 \alpha$ (HIF- $1 \alpha$ ) may promote cell survival in hypoxic or ischemic brain. To help understand the role of HIF-1 $\alpha$ in neonatal hypoxic-ischemic brain injury, mice with conditional neuron-specific inactivation of HIF-1 $\alpha$ underwent hypoxia-ischemia (HI). Mice heterozygous for Cre recombinase under the control of the calcium/calmodulin-dependent kinase II promoter were bred with homozygous 'floxed' HIF-1 $\alpha$ transgenic mice. The resulting litters produced mice with a forebrain predominant neuronal deletion of HIF-1 $\alpha\left(\mathrm{HIF}-1 \alpha^{\Delta / \Delta}\right)$, as well as littermates without the deletion. In order to verify reduction of HIF-1 $\alpha$ at postnatal day $7, \mathrm{HIF}-1 \alpha^{\Delta / \Delta}$ and wild-type mice were exposed to a hypoxic stimulus ( $8 \%$ oxygen) or room air for $1 \mathrm{~h}$, followed by immediate collection of brain cortices for determination of HIF-1 $\alpha$ expression. Results of Western blotting of mouse cortices exposed to hypoxia stimulus or room air confirmed that HIF- $1 \alpha^{\Delta / \Delta}$ cortex expressed a minimal amount of HIF-1 $\alpha$ protein compared to wild-type cortex with the same hypoxic stimulus. Subsequently, pups underwent the Vannucci
\end{abstract}

procedure of $\mathrm{HI}$ at postnatal day 7: unilateral ligation of the right common carotid artery followed by 30 min of hypoxia (8\% oxygen). Immunofluorescent staining of brains $24 \mathrm{~h}$ after $\mathrm{HI}$ confirmed a relative lack of HIF- $1 \alpha$ in the HIF- $1 \alpha^{\Delta / \Delta}$ cortex compared to the wild type, and that HIF-1 $\alpha$ in the wild type is located in neurons. HIF- $1 \alpha$ expression was determined in mouse cortex $24 \mathrm{~h}$ after $\mathrm{HI}$. Histological analysis for the degree of injury was performed 5 days after HI. HIF- $1 \alpha$ protein expression $24 \mathrm{~h}$ after $\mathrm{HI}$ showed a large increase of HIF-1 $\alpha$ in the hypoxic-ischemic cortex of the wild-type compared to the hypoxic only cortex. Histological analysis revealed that $\mathrm{HI}$ injury was increased in the neuronally deficient HIF-1 $\alpha^{\Delta / \Delta}$ mouse brain $(p<0.05)$ and was more severe in the cortex. Genetic reduction of neuronal HIF- $1 \alpha$ results in a worsening of injury after neonatal $\mathrm{HI}$, with a region-specific role for HIF-1 $\alpha$ in the setting of neonatal brain injury.

Copyright $\odot 2009$ S. Karger AG, Basel

\section{Introduction}

Hypoxia-inducible factor $1 \alpha$ (HIF- $1 \alpha)$ is a transcription factor that is essential for the activation of over 40 hypoxia-inducible genes, such as erythropoietin, glucose transporters, glycolytic enzymes, and vascular endothelial growth factor (VEGF) $[1,2]$. Thus, HIF-1 $\alpha$ has a wide-

\section{KARGER}

() 2009 S. Karger AG, Basel

Fax +41613061234 E-Mail karger@karger.ch www.karger.com www.karger.com/dne
R. Ann Sheldon

Department of Neurology, University of California

521 Parnassus Avenue, Box 0663

San Francisco, CA 94143-0663 (USA)

Tel. +1 415514 1779, E-Mail ann.sheldon@ucsf.edu 
ranging role in the cellular response to hypoxia, and in some pathological circumstances, such as tumor growth, its role is increasingly well established $[3,4]$. In the brain, however, where oxygen homoeostasis is of critical importance, the role of HIF-1 $\alpha$, whether physiologic or pathologic, is less well understood. Hypoxia induces many of the genes regulated by HIF- $1 \alpha$ in the brain $[5,6]$, and preconditioning with hypoxia may induce HIF- $1 \alpha$ and promote cell survival in the subsequently hypoxic or ischemic brain [7].

Increased expression of HIF- $1 \alpha$-dependent genes, such as VEGF [8, 9], several glycolytic enzymes [10], glucose transporter 1 [10] and erythropoietin [11-14], is thought to be important in recovery from hypoxia-ischemia (HI) and stroke in the neonatal brain. In fact, evidence suggests that hypoxia preconditioning protection depends on gene expression induced by activation of HIF- $1 \alpha$, since the functions of the HIF- $1 \alpha$ target genes are to increase blood flow, promote angiogenesis, stimulate glucose and lactate delivery to cells, enhance metabolism and promote growth and repair in neurons $[4,15-$ 17]. An ischemic insult can also lead to induction of HIF$1 \alpha$ and its target gene, VEGF, as has been reported following neonatal focal ischemia in the rat [18]. In addition, it has been shown in vitro that the neuroprotective effects of deferoxamine are mediated, at least in part, through induction and stabilization of HIF-1 $\alpha$ [19]. Subsequently, we showed that deferoxamine treatment after middle cerebral artery occlusion in neonatal rats is protective and prolongs the expression of HIF- $1 \alpha$ compared to saline-treated rats. The HIF- $1 \alpha$ target gene erythropoietin was also upregulated in the protected brains [9].

We explored the effect of neuron-specific reduction of HIF-1 $\alpha\left(\mathrm{HIF}-1 \alpha^{\Delta / \Delta}\right)$ on neonatal hypoxic-ischemic brain injury. We employed a well-characterized model of neonatal $\mathrm{HI}$ in HIF-1 $\alpha^{\Delta / \Delta}$ compared to wild-type (Wt) littermates, and found increased cortical injury.

\section{Materials and Methods}

\section{Animals}

All animal research was approved by the University of California San Francisco Institutional Animal Care and Use Committee and was performed with the highest standards of care under the National Institutes of Health guidelines. Mice with conditional neuron-specific inactivation of HIF-1 $\alpha$ were generated using Cre/Lox technology. These mice have previously been well characterized $[20,21]$. Briefly, the deletion was attained by breeding mice that have loxP-containing 'floxed' HIF-1 $\alpha$ alleles with mice expressing Cre recombinase under the control of the calcium/calmodulin-dependent kinase II promoter [22]. The mice containing the Cre transgene used were of the 'Rlag\#5' line [23]. The resulting litters produced mice with a forebrain predominant, neuron-specific deletion of HIF-1 $\alpha\left(\mathrm{HIF}-1 \alpha^{\Delta / \Delta}\right)$, as well as littermates without the deletion. All mice negative by PCR for the Cre gene were considered 'wild-type (Wt)'. Genotyping was carried out by PCR on tail DNA samples using standard methods.

Hypoxic Stimulus Alone

At postnatal day 7 (P7), mice were placed in chambers maintained at $37^{\circ} \mathrm{C}$ and subjected to $1 \mathrm{~h}$ of $8 \%$ oxygen, or room air. Brain cortices were collected immediately after the hypoxia period, snap frozen and stored at $-80^{\circ} \mathrm{C}$ for HIF- $1 \alpha$ protein determination by Western blot.

\section{Hypoxia-Ischemia}

At P7, mice underwent the Vannucci procedure of neonatal HI $[24,25]$. Briefly, under isoflurane anesthesia, the right common carotid artery was permanently ligated. Following a $90-\mathrm{min}$ recovery period, mice were exposed to hypoxia for $30 \mathrm{~min}$ ( $8 \%$ oxygen, balance nitrogen) while being maintained at $37^{\circ} \mathrm{C}$. We have previously shown that the background mouse strain, $\mathrm{C} 57 \mathrm{Bl} / 6$, while somewhat resistant to injury from HI, has high mortality [26]. By using $30 \mathrm{~min}$ of hypoxia, we had a minimal amount of mortality, with moderate injury. At either $24 \mathrm{~h}$ (for immunofluorescence) or 5 days after HI (for scoring of the degree of injury), mice were perfused with $4 \%$ paraformaldehyde in $0.1 \mathrm{M}$ phosphate buffer, brains were removed, and processed histologically. The 5-day post-HI brains were analyzed for the degree of injury using a scoring system as previously described [26]. In addition, some mice were perfused with saline and a piece of contralateral cortex was obtained for Western blot to confirm the tail DNA PCR results. These brains were then immersion-fixed in paraformaldehyde prior to histological preparation as above.

\section{Immunofluorescence}

Flash-frozen mouse brains were cut on a cryostat and $12-\mu \mathrm{m}$ sections collected on glass slides. Brain sections were treated with $2 \mathrm{~N} \mathrm{HCl}$ for $10 \mathrm{~min}$ at $37^{\circ} \mathrm{C}$ and then with $0.5 \mathrm{M}$ boric acid ( $\mathrm{pH} 8.4$ ) for $10 \mathrm{~min}$ at room temperature. After a 2-min rinse with PBS, a blocking solution composed of PBS, $10 \%$ goat serum and $0.3 \%$ Triton X-100 was applied for $1 \mathrm{~h}$. The primary antibodies against HIF-1 $\alpha$ (1:100, Santa Cruz Biotechnology) and NeuN (1:100, Millipore) in a similar blocking solution (2.5\% goat serum) were applied overnight at $4{ }^{\circ} \mathrm{C}$. After washing, secondary antibodies (1:1,000, Alexa Fluor 488 and 568, Invitrogen) in a blocking solution were applied for $1 \mathrm{~h}$ at room temperature. After rinsing in PBS, DAPI staining was applied for $5 \mathrm{~min}$ and thereafter the sections were coverslipped with ProLong Gold (Invitrogen). Images were taken with a Nikon spectral confocal microscope at the Nikon Imaging Center, University of California San Francisco.

\section{Western Blot Analysis}

We first determined HIF-1 $\alpha$ expression with and without a hypoxic stimulus, in which P7 HIF- $1 \alpha^{\Delta / \Delta}(\mathrm{n}=8)$ and Wt $(\mathrm{n}=6)$ mice were exposed to hypoxia ( $8 \%$ oxygen) or room air for $1 \mathrm{~h}$. Brain cortices were collected immediately after the hypoxia period, snap frozen and stored at $-80^{\circ} \mathrm{C}$ until use. Another group of mice underwent $\mathrm{HI}$ at $\mathrm{P} 7$ and cortices were collected, as above, $24 \mathrm{~h}$ later. Western blots were subsequently performed for HIF$1 \alpha$ : in brief, cortices were homogenized in ice-cold lysis buffer 


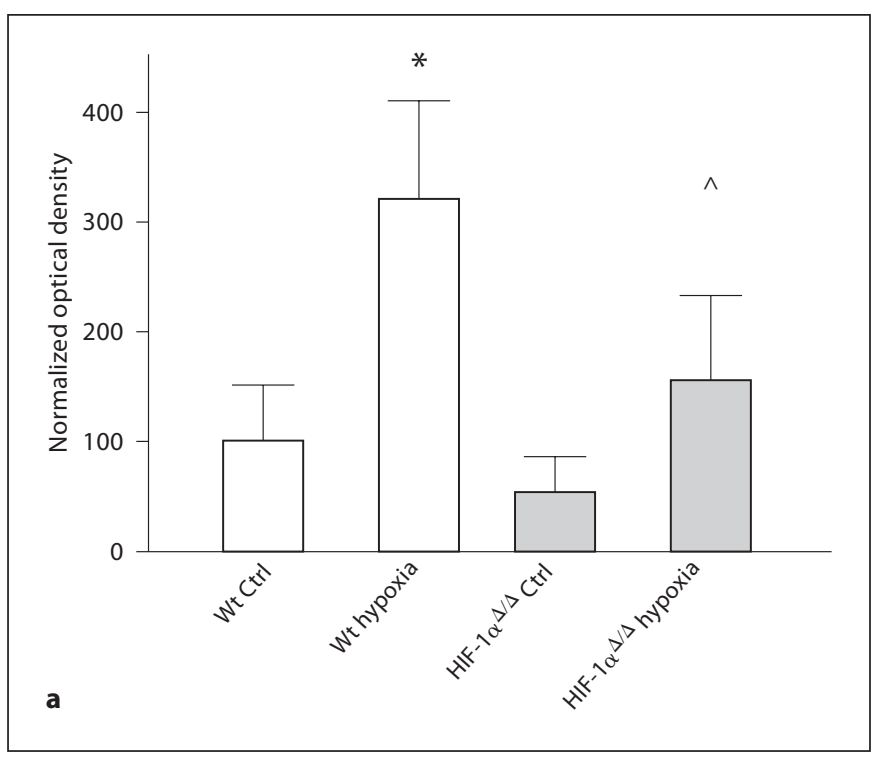

Fig. 1. HIF- $1 \alpha$ protein expression. a HIF- $1 \alpha$ protein expression in P7 mouse cortices, with or without 1 h of $8 \%$ oxygen exposure, by Western blot analysis. Optical densities are normalized to $\beta$-actin and values are expressed as mean \pm SD of optical densities normalized to Wt control (Ctrl). HIF-1 $\alpha$ protein expression is higher in hypoxic $\mathrm{Wt}\left({ }^{*}\right)$ compared to all other groups: Wt naïve control $(\mathrm{p}<0.05)$, HIF-1 $\alpha^{\Delta / \Delta}$ naïve control $(\mathrm{p}<0.01)$, and HIF- $1 \alpha^{\Delta / \Delta}$ hypoxia $(\mathrm{p}<0.04)$. In addition, HIF- $1 \alpha^{\Delta / \Delta}$ with hypoxia has higher HIF- $1 \alpha$ protein levels than HIF- $1 \alpha^{\Delta / \Delta}$ control $(\wedge p<0.05)$. For Wt control, Wt hypoxia and HIF- $1 \alpha^{\Delta / \Delta}, \mathrm{n}=3$; for HIF- $1 \alpha^{\Delta / \Delta}$ hypoxia, $\mathrm{n}=5$. Analysis by ANOVA with the Bonferroni multiple comparison test. b HIF-1 $\alpha$ protein expression in mouse cortices $24 \mathrm{~h}$ after $\mathrm{HI}$ at P7. The Wt cortex ipsilateral (ipsi) to HI injury $\left({ }^{*} \mathrm{n}=\right.$

containing sodium chloride ( $150 \mathrm{mM})$, Tris- $\mathrm{HCl}$ (50 mM, $\mathrm{pH} 8.0)$, NP-40 (1\%), DOC (0.5\%), SDS (0.1\%), PMSF (0.5 mM), and the protease inhibitors aprotinin and leupeptin. The homogenates were centrifuged at $14,000 \mathrm{rpm}$ for $30 \mathrm{~min}$ at $4^{\circ} \mathrm{C}$, and the protein concentration of the supernatants determined by BCA (Pierce, Rockwell, Md., USA). Protein samples were diluted in SDS-PAGE sample buffer, boiled for $5 \mathrm{~min}$ and separated by SDS-PAGE. Proteins were transferred to polyvinylidene fluoride membranes, which were blocked in 5\% non-fat dry milk in TBS, with $0.05 \%$ Tween 20 for $1 \mathrm{~h}$ at room temperature. After blocking, membranes were incubated with mouse anti-HIF-1 $\alpha$ monoclonal antibody (Santa Cruz Biotechnology, Santa Cruz, Calif., USA, 1:200) for $1 \mathrm{~h}$ at room temperature, then overnight at $4^{\circ} \mathrm{C}$. Rabbit anti$\beta$-actin polyclonal antibody (Sigma, St. Louis, Mo., USA, 1:200) was detected on the immunoblots to ensure equal protein loading. Following washes, the membranes were incubated with HRPconjugated goat anti-mouse IgG (Santa Cruz, 1:3,000) in blocking solution for $1 \mathrm{~h}$. After further washes, the signal of bound antibody was captured on X-ray film with enhanced chemiluminescence (Pierce, Rockford, Ill., USA). NIH Image was used to measure the densities of the protein signals after being scanned. Optical density of the protein bands was measured following

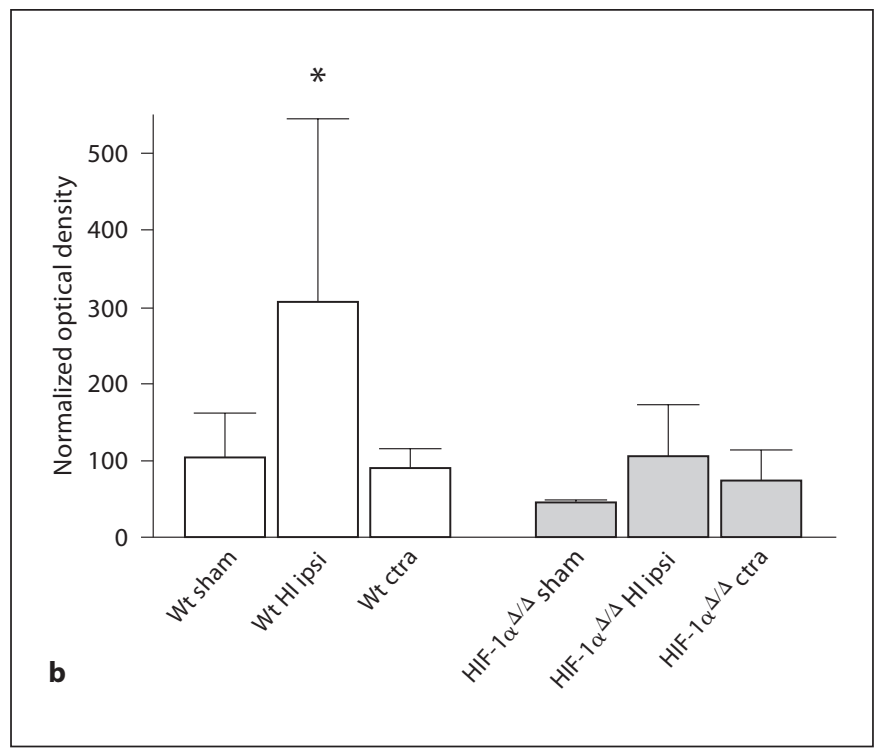

5) has increased HIF-1 $\alpha$ protein expression compared to all other groups: Wt contralateral (ctra) to $\mathrm{HI}(\mathrm{p}<0.01, \mathrm{n}=5) \mathrm{Wt}$ sham $(\mathrm{p}<0.01, \mathrm{n}=7)$, HIF-1 $\alpha^{\Delta / \Delta}$ sham $(\mathrm{p}<0.01)$, HIF- $1 \alpha^{\Delta / \Delta}$ ipsilateral to HI injury $(\mathrm{p}<0.01)$ and HIF-1 $\alpha^{\Delta / \Delta}$ contralateral to HI injury $(\mathrm{p}<0.001)$. There are no significant differences among the three HIF- $1 \alpha^{\Delta / \Delta}$ groups. However, there is a trend for higher HIF-1 $\alpha$ protein expression in the HIF- $1 \alpha^{\Delta / \Delta}$ cortex ipsilateral to HI injury $(\mathrm{n}=9)$ compared to HIF- $1 \alpha^{\Delta / \Delta}$ sham $(\mathrm{p}<0.06, \mathrm{n}=4)$ and contralateral to $\mathrm{HI}(\mathrm{p}=0.10, \mathrm{n}=9)$. Optical densities are normalized to $\beta$-actin and values are expressed as optical densities normalized to Wt sham (mean \pm SD). Analysis by ANOVA with the Bonferroni multiple comparison test.

subtraction of the film background and protein levels were normalized to $\beta$-actin. All experiments were repeated at least three times to ensure reproducibility of results.

\section{Statistical Analysis}

For the histological scoring of brain injury, significance was determined by the Mann-Whitney test. For the Western blots, ANOVA with the Bonferroni test for multiple comparisons was used. Significance was set at $\mathrm{p}<0.05$. Analysis was done with Prism 4.0 (Graphpad Software Inc.).

\section{Results}

\section{$H I F-1 \alpha$ Protein Expression}

We confirmed that HIF-1 $\alpha$ is upregulated in the cortex immediately after a hypoxic insult. Specifically, HIF$1 \alpha$ protein expression is increased in Wt cortex after a hypoxic stimulus compared to Wt naïve control $(\mathrm{p}<0.05)$ and to HIF- $1 \alpha^{\Delta / \Delta}$ naïve control ( $\left.\mathrm{p}<0.01\right)$. There is also an 

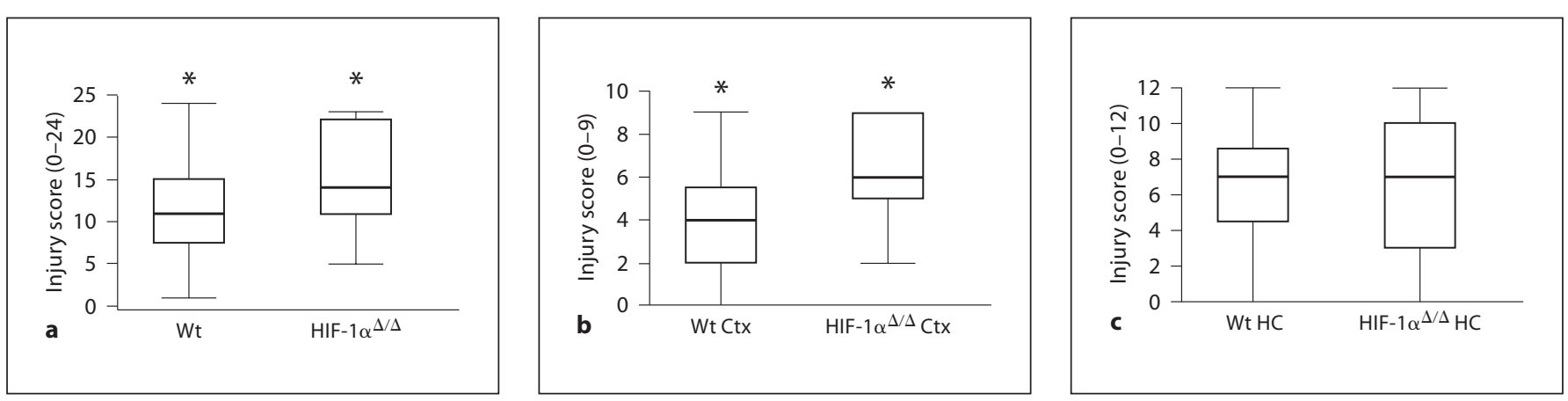

Fig. 2. HI brain injury 5 days after HI. a Total brain injury score (scale $0-24)$. HIF-1 $\alpha^{\Delta / \Delta}$ mice (median $14, \mathrm{n}=11$ ) are more injured than Wt (median 11, $\mathrm{n}=27)\left({ }^{*} \mathrm{p}<0.05\right)$. b Cortical injury (scale $0-9)$. HIF- $1 \alpha^{\Delta / \Delta}$ cortices (Ctx) (median =6) are more injured than Wt cortices (median $=4)\left({ }^{*} \mathrm{p}<0.01\right)$. c Hippocampal injury (scale

increase in protein expression in the HIF- $1 \alpha^{\Delta / \Delta}$ cortex with hypoxic stimulus compared to HIF- $1 \alpha^{\Delta / \Delta}$ naïve control ( $\mathrm{p}<0.05)$ (fig. 1a), indicating the presence of some cells that produce HIF- $1 \alpha$.

Western blot analysis of brain cortices collected $24 \mathrm{~h}$ after HI (fig. 1b) shows that the Wt cortex $(n=5)$ has a level of HIF-1 $\alpha$ protein more than twice as high as the $\mathrm{Wt}$ sham cortex $(\mathrm{n}=7 ; \mathrm{p}<0.05)$ and the Wt cortex contralateral to $\mathrm{HI}$ (hypoxic, $\mathrm{n}=5 ; \mathrm{p}<0.01$ ). The Wt HI cortex also had higher HIF-1 $\alpha$ protein levels than all HIF- $1 \alpha^{\Delta / \Delta}$ groups: sham $(\mathrm{p}<0.01)$, ipsilateral to $\mathrm{HI}(\mathrm{p}<0.01)$ and contralateral $(\mathrm{p}<0.001)$. In the HIF- $1 \alpha^{\Delta / \Delta}$ groups, there is a trend toward increased HIF-1 $\alpha$ levels in the HI cortex $(\mathrm{n}=9)$ compared to sham $(\mathrm{n}=4)(\mathrm{p}<0.06)$ and contralateral cortices $(\mathrm{p}=0.10)$.

\section{Histological Analysis for Degree of Injury}

Histological analysis of brains 5 days after HI demonstrates an increase in injury in the HIF- $1 \alpha^{\Delta / \Delta}$ mouse brain compared to Wt brain (fig. 2a: median scores, Wt $=11$, HIF- $\left.1 \alpha^{\Delta / \Delta}=14, \mathrm{p}<0.05\right)$. This injury is more severe in the cortex of the HIF-1 $1 \alpha^{\Delta / \Delta}$ brain compared to Wt brain (fig. $2 \mathrm{~b}$ : median $\mathrm{Wt}=4$, HIF- $1 \alpha^{\Delta / \Delta}=6, \mathrm{p}<0.01$ ), than in the hippocampus, where there was no difference in degree of injury (fig. 2c: median Wt $=7$, HIF-1 $\alpha^{\Delta / \Delta}=7, \mathrm{p}>$ 0.75). The total number of Wt mice was 27 (13 male, 14 female); the total number of HIF-1 $\alpha^{\Delta / \Delta}$ mice was 11 (8 male, 3 female). There is no effect on injury score associated with sex, although the number of females in the HIF$1 \alpha^{\Delta / \Delta}$ group, while adequate, is small compared to males and thus may limit this analysis.

HIF-1 $\alpha$ in Neonatal Hypoxia-Ischemia
$0-12)$. There is no difference in hippocampal injury between groups (median $=7$ for both, $\mathrm{p}>0.75$ ). The horizontal line within the box represents the median injury score for each group. Analysis by the Mann-Whitney test. HC = Hippocampus.

\section{Immunofluorescence}

Immunofluorescent staining of Wt (fig. 3a-d) and HIF- $1 \alpha^{\Delta / \Delta}$ (fig. 3e-h) brain $24 \mathrm{~h}$ after HI indicates a relative lack of HIF- $1 \alpha$ in the HIF-1 $\alpha^{\Delta / \Delta}$ cortex (fig. 3f) compared to Wt (fig. 3b). Double-labelling with NeuN demonstrates that HIF-1 $\alpha$ is localized primarily in neurons in the Wt cortex (fig. 3c). Double-labelling is virtually absent in the HIF-1 $1 \alpha^{\Delta / \Delta}$ brain (fig. 3g). A small amount of nonneuronal HIF-1 $\alpha$ appears to be present in $\mathrm{Wt}$, and possibly to an even lesser extent in HIF- $1 \alpha^{\Delta / \Delta}$ brains (small red dots). The addition of DAPI shows the nucleus in relation to HIF-1 $\alpha$ and NeuN (fig. 3d, h).

\section{Discussion}

We hypothesized that HIF-1 $\alpha$ serves to protect the neonatal brain from injury due to HI, and this study supports this hypothesis, since genetic reduction of HIF- $1 \alpha$ in the mouse forebrain leads to a greater degree of injury. While it is well established that HIF-1 $\alpha$ is the primary regulator of oxygen homeostasis [15], its role in injury and disease has yet to be fully understood. However, HIF$1 \alpha$ may be especially important in the developing brain. The developing brain is particularly vulnerable to oxidative stress, with its high rate of oxygen consumption, low concentrations of antioxidants and availability of redoxactive iron $[27,28]$. The fact that HIF- $1 \alpha$ and its target gene, VEGF, have an important role in angiogenesis indicates potential for repair after brain injury. It has recently been shown in the adult ischemic brain, for example, that neural stem/progenitor cells have a role in vas- 

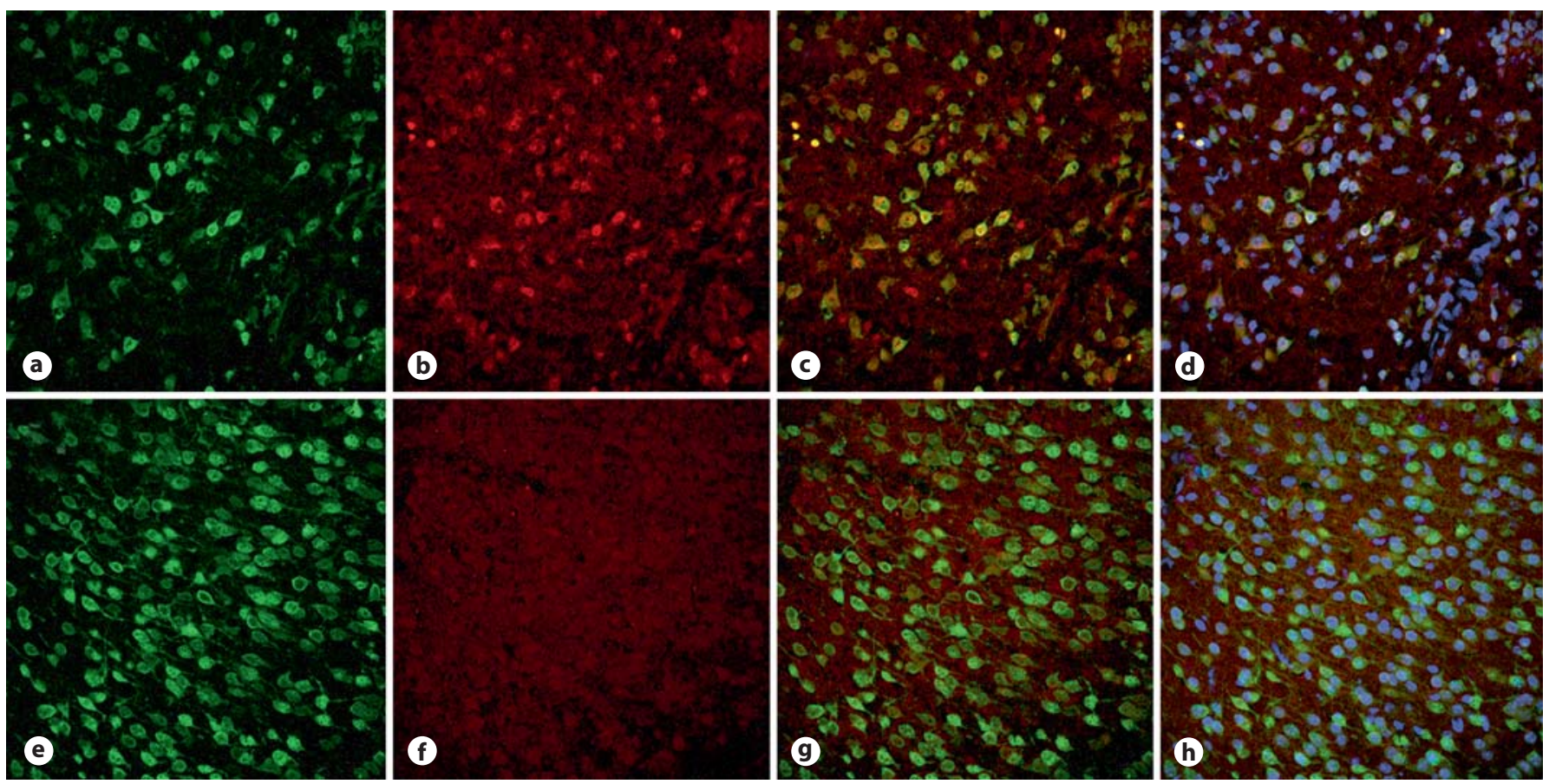

Fig. 3. Localization of HIF- $1 \alpha$ by immunofluorescent staining Immunofluorescently labeled cells in the cortex of representative Wt (a-d) and HIF- $1 \alpha^{\Delta / \Delta}(\mathbf{e}-\mathbf{h})$ brains $24 \mathrm{~h}$ after HI at P7.

a, e NeuN. b, f HIF-1 $\alpha$. c, g Merged NeuN and HIF-1 $\alpha$. Yellow cells indicate localization of HIF-1 $\alpha$, where present, to neurons. d, $\mathbf{h}$ NeuN, HIF-1 $\alpha$ and DAPI for visualization of nuclei.

cular stabilization, which is mediated via HIF- $1 \alpha$-VEGF signaling pathways [29]. In neonatal $\mathrm{HI}$ in the rat, exogenously applied VEGF (via intracerebroventricular injection) is neuroprotective [30]. Increased expression and stabilization of HIF-1 $\alpha$ after neonatal brain injury may also be associated with neurogenesis and repair $[9,31]$.

While we hypothesized that a lack of HIF-1 $\alpha$ would exacerbate neonatal HI injury (but have confirmed that here in the developing mouse brain), there is conflicting evidence on whether HIF-1 $\alpha$ is beneficial or detrimental. In a different line of neural cell-specific HIF-1 $\alpha$-deficient mice than we used, defective brain development was seen embryonically, leading to defects including hydrocephalus in the adult [32]. The mice we used do not express the deletion of HIF-1 $\alpha$ embryonically; the deleted HIF-1 $\alpha$ allele is detectable by Southern blot beginning at P5 [20]. In addition, all mice we used appeared normal both as neonates and adults. Reports from studies in adult ischemia have shown conflicting evidence in regard to the role of HIF- $1 \alpha$ in this same line of transgenic mice. In a model of global ischemia, which produces a distinct pattern of injury, HIF- $1 \alpha^{\Delta / \Delta}$ brains had less injury than Wt counterparts [21]. On the other hand, with transient focal cere- bral ischemia, HIF- $1 \alpha^{\Delta / \Delta}$ brains had increased injury and reduced survival compared to Wt counterparts [20]. Recently, in a rat model of neonatal HI, acute, but not delayed, pharmacological inhibition of HIF-1 $\alpha$ resulted in reduced injury [33]. In this study, we chose to produce a moderate degree of HI injury for two reasons: to keep mortality low, and to avoid differential effects of severe injury on the induction of death mechanisms $[34,35]$. With our model, genetic reduction of neuronal HIF-1 $\alpha$ resulted in a worsening of injury after neonatal HI, especially to the cortex. We did not measure HIF-1 $\alpha$ in the hippocampi collected from these same brains because HIF- $1 \alpha$ was measured in the nuclear fraction of the homogenate and the small size of the hippocampi prohibits this measurement without pooling samples. It has also been shown that calcium/calmodulin-dependent kinase II is absent in the hippocampal synapse at $\mathrm{P} 2$ and remains very low at P10, increasing dramatically at P35 [36]. Therefore, the lack of effect in the hippocampus may be due to the lack of expression of the promoter needed for deletion of the HIF-1 $\alpha$ gene. In addition, the hippocampus may express other isoforms or have differential susceptibility to the injury. 
We have previously shown that HIF-1 $\alpha$ upregulation peaks at $8 \mathrm{~h}$ after transient ischemia in neonatal rats, and declines at $24 \mathrm{~h}$ [9]. Here, while it is clear that HIF- $1 \alpha$ is upregulated in Wt cortex immediately after hypoxia, and also at $24 \mathrm{~h}$ after HI, it remains for the future to be determined at what time point peak expression in the Wt cortex lies. There may also be a region-specific role for HIF$1 \alpha$ in the setting of neonatal brain injury, since we found a difference in the degree of injury in the cortex, but not the hippocampus, when compared to Wt.

Given the large number of genes regulated by HIF- $1 \alpha$ and the disparate outcomes of HIF-1 $\alpha$ studies, based on different rodent species, ages, and models, it seems likely that a number of factors influence whether HIF- $1 \alpha$ has a deleterious or a protective effect. This may be due, in part, to the variable functions of different cell types and how they interact [37]. A recent study of neurons and astrocytes in co-culture showed that loss of HIF-1 $\alpha$ function in neurons reduced neuronal viability after hypoxia, yet selective loss of HIF-1 $\alpha$ function in astrocytes protected neurons from hypoxia. This indicates that HIF-1 $\alpha$ may not only have different roles depending on cell type, but that role may be critical to survival [38].

Thus, the specific circumstances we have explored here may well have produced results specific to the developing brain. Whether HIF-1 $\alpha$ acts to promote or prevent injury is of critical importance in our quest to develop therapies for the human infant, as a greater understanding of the role of HIF-1 $\alpha$ in neonatal hypoxic-ischemic brain injury may lead to new avenues for therapies and improve outcome for babies affected by HI.

\section{Acknowledgements}

We are grateful to Dr. Carrollee Barlowe for the provision of our initial HIF F/w mice and Dr. Ioannis Dragatsis for the Cre-tg mice used to generate the mice used in these experiments. Kevin Lui contributed technical assistance. This work was funded by NIH R01NS033997 (D.M.F.), and the National Natural Scientific Foundation of China No. 30770748 and No. 30825039 (D.M.).

\section{References}

1 Bernaudin M, Tang Y, Reilly M, Petit E, Sharp FR: Brain genomic response following hypoxia and re-oxygenation in the neonatal rat. Identification of genes that might contribute to hypoxia-induced ischemic tolerance. J Biol Chem 2002;277:39728-39738.

-2 Ran R, Xu H, Lu A, Bernaudin M, Sharp FR: Hypoxia preconditioning in the brain. Dev Neurosci 2005;27:87-92.

3 Weidemann A, Johnson RS: Biology of HIF1-alpha. Cell Death Differ 2008;15:621-627.

-4 Semenza GL: HIF-1: mediator of physiological and pathophysiological responses to hypoxia. J Appl Physiol 2000;88:1474-1480.

5 Jones NM, Bergeron M: Hypoxic preconditioning induces changes in HIF-1 target genes in neonatal rat brain. J Cereb Blood Flow Metab 2001;21:1105-1114.

-6 Jones NM, Lee EM, Brown TG, Jarrott B, Beart PM: Hypoxic preconditioning produces differential expression of hypoxia-inducible factor-1-alpha (HIF-1-alpha) and its regulatory enzyme HIF prolyl hydroxylase 2 in neonatal rat brain. Neurosci Lett 2006;404: 72-77.

7 Bergeron M, Gidday JM, Yu AY, Semenza GL, Ferriero DM, Sharp FR: Role of hypoxiainducible factor-1 (HIF-1) in hypoxia-induced ischemic tolerance in neonatal rat brain. Ann Neurol 2000;48:285-296.
id induction of vascular endothelial growth factor gene expression after transient middle cerebral artery occlusion in rats. Stroke 1997; 28:2039-2044.

-9 Mu D, Chang YS, Vexler ZS, Ferriero DM: Hypoxia-inducible factor 1 alpha and erythropoietin upregulation with deferoxamine salvage after neonatal stroke. Exp Neurol 2005;195:407-415.

10 Bergeron M, Yu AY, Solway KE, Semenza GL, Sharp FR: Induction of hypoxia-inducible factor-1 (HIF-1) and its target genes following focal ischaemia in rat brain. Eur J Neurosci 1999;11:4159-4170.

$\checkmark 11$ Kumral A, Uysal N, Tugyan K, Sonmez A, Yilmaz O, Gokmen N, Kiray M, Genc S, Duman N, Koroglu TF, Ozkan H, Genc K: Erythropoietin improves long-term spatial memory deficits and brain injury following neonatal hypoxia-ischemia in rats. Behav Brain Res 2004;153:77-86.

12 Matsushita H, Johnston MV, Lange MS, Wilson MA: Protective effect of erythropoietin in neonatal hypoxic ischemia in mice. Neuroreport 2003; 14:1757-1761.

13 Chang YS, Mu D, Wendland M, Sheldon RA, Vexler ZS, McQuillen PS, Ferriero DM: Erythropoietin improves functional and histological outcome in neonatal stroke. Pediatr Res 2005;58:106-111.
14 Gonzalez FF, McQuillen P, Mu D, Chang Y, Wendland M, Vexler Z, Ferriero DM: Erythropoietin enhances long-term neuroprotection and neurogenesis in neonatal stroke. Dev Neurosci 2007;29:321-330.

15 Semenza GL: Hypoxia-inducible factor 1: master regulator of $\mathrm{O}_{2}$ homeostasis. Curr Opin Genet Dev 1998;8:588-594.

16 Sharp FR, Bernaudin M: HIF-1 and oxygen sensing in the brain. Nat Rev Neurosci 2004; 5:437-448.

17 Chang S, Jiang X, Zhao C, Lee C, Ferriero DM: Exogenous low dose hydrogen peroxide increases hypoxia-inducible factor-1-alpha protein expression and induces preconditioning protection against ischemia in primary cortical neurons. Neurosci Lett 2008; 441:134-138.

$-18 \mathrm{Mu}$ D, Jiang X, Sheldon RA, Fox CK, Hamrick SE, Vexler ZS, Ferriero DM: Regulation of hypoxia-inducible factor 1-alpha and induction of vascular endothelial growth factor in a rat neonatal stroke model. Neurobiol Dis 2003; 14:524-534.

19 Hamrick SEG, McQuillen PS, Madan A, Ferriero DM: Mechanisms of desferoxamine neuroprotection: a role for HIF-1-alpha. Pediatr Res 2003;53:25A.

20 Baranova O, Miranda LF, Pichiule P, Dragatsis I, Johnson RS, Chavez JC: Neuron-specific inactivation of the hypoxia inducible factor 1 alpha increases brain injury in a mouse model of transient focal cerebral ischemia. J Neurosci 2007;27:6320-6332. 
-21 Helton R, Cui J, Scheel JR, Ellison JA, Ames C, Gibson C, Blouw B, Ouyang L, Dragatsis I, Zeitlin S, Johnson RS, Lipton SA, Barlowe C: Brain-specific knock-out of hypoxia-inducible factor-1-alpha reduces rather than increases hypoxic-ischemic damage. J Neurosci 2005;25:4099-4107.

-22 Ryan HE, Poloni M, McNulty W, Elson D, Gassmann M, Arbeit JM, Johnson RS: Hypoxia-inducible factor-1-alpha is a positive factor in solid tumor growth. Cancer Res 2000;60:4010-4015.

-23 Dragatsis I, Zeitlin S: CaMKII-alpha-Cre transgene expression and recombination patterns in the mouse brain. Genesis 2000; 26:133-135.

-24 Rice JE 3rd, Vannucci RC, Brierley JB: The influence of immaturity on hypoxic-ischemic brain damage in the rat. Ann Neurol 1981;9:131-141.

-25 Ditelberg JS, Sheldon RA, Epstein CJ, Ferriero DM: Brain injury after perinatal hypoxia-ischemia is exacerbated in copper/zinc superoxide dismutase transgenic mice. Pediatr Res 1996;39:204-208.

-26 Sheldon RA, Sedik C, Ferriero DM: Strainrelated brain injury in neonatal mice subjected to hypoxia-ischemia. Brain Res 1998; 810:114-122.

-27 Ferriero DM: Neonatal brain injury. N Engl J Med 2004;351:1985-1995.
28 McQuillen PS, Ferriero DM: Selective vulnerability in the developing central nervous system. Ped Neurol 2004;30:227-235.

29 Roitbak T, Li L, Cunningham LA: Neural stem/progenitor cells promote endothelial cell morphogenesis and protect endothelial cells against ischemia via HIF-1-alpha-regulated VEGF signaling. J Cereb Blood Flow Metab 2008;28:1530-1542.

30 Feng Y, Rhodes PG, Bhatt AJ: Neuroprotective effects of vascular endothelial growth factor following hypoxic-ischemic brain injury in neonatal rats. Pediatr Res 2008;64: 370-374.

31 Zhao T, Zhang CP, Liu ZH, Wu LY, Huang X, Wu HT, Xiong L, Wang X, Wang XM, Zhu LL, Fan M: Hypoxia-driven proliferation of embryonic neural stem/progenitor cells Role of hypoxia-inducible transcription factor-1-alpha. FEBS J 2008;275:1824-1834.

-32 Tomita S, Ueno M, Sakamoto M, Kitahama Y, Ueki M, Maekawa N, Sakamoto $H$, Gassmann M, Kageyama R, Ueda N, Gonzalez FJ, Takahama Y: Defective brain development in mice lacking the HIF-1-alpha gene in neural cells. Mol Cell Biol 2003;23:67396749.
33 Chen W, Jadhav V, Tang J, Zhang JH: HIF-1alpha inhibition ameliorates neonatal brain injury in a rat pup hypoxic-ischemic model. Neurobiol Dis 2008;31:433-431.

34 Ankarcrona M, Dypbukt JM, Bonfoco E, Zhivotovsky B, Orrenius S, Lipton SA, Nicotera P: Glutamate-induced neuronal death: a succession of necrosis or apoptosis depending on mitochondrial function. Neuron 1995; 15:961-973.

35 Portera-Cailliau C, Price DL, Martin LJ: Excitotoxic neuronal death in the immature brain is an apoptosis-necrosis morphological continuum. J Comp Neurol 1997;378:7087.

36 Petralia RS, Sans N, Wang YX, Wenthold RJ: Ontogeny of postsynaptic density proteins at glutamatergic synapses. Mol Cell Neurosci 2005;29:436-452.

37 Mojsilovic-Petrovic J, Callaghan D, Cui H, Dean C, Stanimirovic DB, Zhang W: Hypoxia-inducible factor-1 (HIF-1) is involved in the regulation of hypoxia-stimulated expression of monocyte chemoattractant protein-1 (MCP-1/CCL2) and MCP-5 (CCL12) in astrocytes. J Neuroinflammation 2007;4:12.

38 Vangeison G, Carr D, Federoff HJ, Rempe DA: The good, the bad, and the cell type-specific roles of hypoxia inducible factor-1 alpha in neurons and astrocytes. J Neurosci 2008; 28:1988-1993. 